\title{
Medication information for Flemish inpatients with major depression: evaluation and construct validity of the Consumer Information Rating Form
}

\author{
F. Desplenter* PharmD, G. Laekeman* PhD PharmD, K. Demyttenaere $\dagger$ MD PhD and \\ VZA-Leaflet Research Group ${ }^{1}$; S. Simoens* MSc PhD \\ ${ }^{*}$ Research Centre for Pharmaceutical Care and Pharmaco-economics, Faculty of Pharmaceutical Sciences, \\ Katholieke Universiteit Leuven, Leuven, Belgium and †Department of Neurosciences and Psychiatry, \\ University Hospital Gasthuisberg, Leuven, Belgium
}

\section{SUMMARY}

Background and objectives: Evaluating the quality of written medication information is a major topic of concern when patient pamphlets are developed. The objective of this study is to evaluate a patient pamphlet on selective serotonin reuptake inhibitors (SSRIs) by calculating Flesch-Douma readability scores and by applying the Consumer Information Rating Form (CIRF) to Flemish inpatients with major depression taking SSRIs. Methods: The pamphlet was evaluated by calculating Flesch-Douma readability scores. The study enrolled patients with major depression taking SSRIs. Patient received a SSRI pamphlet and completed a self-administered structured

Received 18 July 2008, Accepted 12 December 2008

Correspondence: Franciska Desplenter, Research Centre for Pharmaceutical Care and Pharmaco-economics, Faculty of Pharmaceutical Sciences, Katholieke Universiteit Leuven, Onderwijs en Navorsing 2, Herestraat 49 PO Box 521, 3000 Leuven, Belgium. Tel.: +32 (0)16 3234 47; fax: +32 (0)16 3234 68; e-mail: Franciska.Desplenter@pharm.kuleuven.be

${ }^{1}$ Pieterjan Callens, MD (University Hospital Leuven, Leuven, Belgium); Cécile De Keyster, PharmD (Psychiatric Hospital Heilige Familie, Kortrijk, Belgium); Katharina De Meulemeester, PharmD (Psychiatric Hospital Sint Camillus, Sint-Denijs-Westrem, Belgium); Tine De Ridder, MD (University Hospital Leuven, Leuven, Belgium); Mieke De Voght, PharmD (Psychiatric Hospital Sint Alexius, Grimbergen, Belgium); Martine Gillis, PharmD (Psychiatric Hospital Sint Jozef, Pittem, Belgium); Inge Jeandarme, MD (Psychiatric Hospital Ziekeren, Sint-Truiden, Belgium); Annemie Van Doren, PharmD (Psychiatric Centre Rekem, Rekem, Belgium); Anne Verhaeghen, MD (University Hospital Leuven, Leuven, Belgium). questionnaire consisting of the adapted CIRF and the Hospital Anxiety and Depression Scale. Construct validity was explored by means of factor analysis and Cronbach's alpha.

Results and discussion: The Flesch-Douma readability scores showed that the pamphlet was easy to read, had much interest in the reader and was very popular. The sample of 96 patients consisted of doubtful/definite cases in terms of anxiety $(10.65 \pm 4.90)$ and doubtful cases in terms of depression $(8 \cdot 91 \pm 5 \cdot 23)$. Using the CIRF, patients assigned positive scores to comprehensibility, utility and design quality of the pamphlet. Factor analysis on the original CIRF confirmed the three original factors $(P<0 \cdot 001)$. Cronbach's alpha of factors ranged from $0 \cdot 69$ to $0 \cdot 83$.

Conclusion: The SSRI pamphlet is of good quality. Our study supported the construct validity of the CIRF to Flemish inpatients with major depression.

Keywords: consumer information rating form, major depression, pamphlet, patient education, written patient information

\section{INTRODUCTION}

High-quality medication information is essential in any strategy to promote health literacy, shared decision-making, medication adherence and self-management $(1,2)$. Since 1999, it has been mandatory that medicines sold within the European Union (EU) are accompanied by a patient information leaflet. But which criteria does written medication information (defined as any written 
materials on medicines for patients) have to meet? In the EU, the requirements for patient information leaflets are specified in Directive 92/27/EEC (31 March 1992): the package leaflet must be written in clear and understandable terms for the patient and be clearly legible in the official language(s). The Action Plan of the U.S. Department of Health and Human Services states that materials should be scientifically accurate; unbiased in content and tone; sufficiently specific and comprehensive; presented in an understandable and legible format that is readily comprehensible to consumers; timely and up-to-date; and useful (i.e. the material enables the consumer to use the medicine properly and appropriately, to receive the maximum benefit and to avoid harm) (3). Similar descriptions of the characteristics of written information can be found in the international literature (4-7). To be effective, patient pamphlets must be noticed, read, understood, believed and remembered (4).

Evaluating written medication information can be carried out from different perspectives $(5,8,9)$. For this purpose, indirect and direct tests have been developed to evaluate written information from multiple perspectives (9). The best known indirect method are the readability formulae based on word and sentence length to estimate reading comprehensibility (10). Readability formulae have their limitations and take no account of the acceptance of the audience. Readability formulae are based on word and sentence length. They fail to asses reading comprehension and design of the material and do not take account for the readers' psychological and cultural background (11-13). To gain insight in the consumers' perceptions, beliefs, comprehension, recall and behaviour, a variety of direct methods have been used: individual interviews, focus groups and self-administered questionnaires (9). The involvement of healthy volunteers in the evaluation of patient information leaflets is mandatory in the EU (so-called consumer testing).

The Consumer Information Rating Form (CIRF) was developed as a direct method for evaluating consumers' perceptions of written patient information (9). It includes perceptions on comprehensibility, utility and design quality. Two studies demonstrated the validity and reliability of the CIRF $(9,14)$. The first study involved a small convenience consumer sample $(n=24)$ in the USA (9). The second study included a larger sample of
Australian consumers $(n=282)$ taking prescription medication for a rheumatology/pain condition or for hypertension (14). These studies evaluated the CIRF in populations of English-speaking patients admitted to acute hospitals and in community pharmacies. One may question the validity of the use of the CIRF when this instrument is employed in new populations with different characteristics.

The provision of information is one of the tasks of a pharmacist. Pharmacists of the Flemish Society of Hospital Pharmacists (division of psychiatry) noticed the need of patient-friendly written information on psychotropic drugs. In the context of a continuing education course in the period 19951998, a group of hospital pharmacists started to develop pamphlets on psychotropic drugs. They continued the development of the pamphlets until now and are updating them on a regular basis. Nowadays, about 30 pamphlets are available including antidepressants, anxiolytics, antiepileptics, antipscyhotics, hypnotics and mood stabilizers. The pamphlet is one A4 paper printed on both sides. The pamphlets are structured in an identical way: they are composed of several questions and provide detailed answers to each question. The questions are based on the following framework: what is this medicine, how do you use the medicine and information concerning safety issues. The content of the pamphlets is based on the summary of product characteristics and was discussed among peers. The pamphlets are available from the Flemish Society of Hospital Pharmacists (division of psychiatry). Nurses as well as psychiatrists and pharmacists use the pamphlets when patients need information on their psychotropic drugs.

The aims of this study are two-fold. First, this study aims to evaluate the readability and the acceptance of a patient pamphlet on SSRI (Selective Serotonin Reuptake Inhibitor) antidepressants designed by the Flemish Society of Hospital Pharmacists (division of psychiatry) based on an indirect and a direct method by using readability formulae and the CIRF questionnaire, respectively. Second, this study aims to explore the construct validity of the CIRF to a population of Dutchspeaking inpatients with major depression.

The added value of this study is the exploration of the construct validity of the CIRF to patients 
with different characteristics. This is the first study in which patients with a mental health problem are involved and the first time the CIRF is used in a non-English language other than English. The findings can support the further use of the CIRF in the evaluation of written medication information.

\section{METHODS}

\section{Indirect evaluation}

The Flesch readability formulae were applied to the patient pamphlet on SSRIs (10). The formulae assess three parameters: 'reading ease', 'human interest' and 'quick reading' test. The scores for the three parameters were calculated according to Douma using coefficients adapted to Dutch (see Appendix 1) (15, 16).

\section{Direct evaluation}

Patient sample. As psychiatric inpatients have a need for medication information, it is essential to evaluate the quality of medication information provided to this patient population (17). Seven Flemish psychiatric hospitals participated in this study. The local investigators were pharmacists and included patients in the study in collaboration with the staff of the hospital wards (nurses and psychiatrists) according to the inclusion criteria. Patients were eligible if they were at least 18 years old, were Dutch-speaking, and had the primary diagnosis of major depression at the moment of hospital admission. Patients took an SSRI antidepressant (i.e. citalopram, escitalopram, fluoxetine, fluvoxamine, sertraline or paroxetine). In Belgium, half of the patients taking antidepressants get a prescription for a SSRI antidepressant (18). If patients complied with the inclusion criteria, they were asked by the local researcher to participate a few days prior to hospital discharge. When they consented to participate, they received the pamphlet and a structured questionnaire. There was no time restriction to read the pamphlet and to complete the questionnaire. After the patient finished the questionnaire, study documents were returned to the local investigator. All study materials were handled anonymously. This study was approved by the coordinating Ethics Committee of the 'Broeders van Liefde' hospitals.
Structured questionnaire. Patients received a SSRI pamphlet and a self-administered structured questionnaire consisting of several parts: adapted CIRF questionnaire, HADS questionnaire and patient demographic data form.

The SSRI pamphlet is a patient information pamphlet written by hospital pharmacists employed in psychiatric hospitals (see Appendix 2). The pamphlet is composed of eight questions and provides detailed answers to each question: 'Why do I get SSRI prescribed?', 'What are SSRI's?', 'Are SSRI's safe?', 'How do I take my SSRI?', 'What do I feel after taking my SSRI?', 'Are there any side effects?', 'Can I use alcohol?' and 'I feel better, can I stop them?'. There were no separate pamphlets on the individual SSRIs as they are considered to make up one pharmacological class.

The original CIRF consists of three main questions: the 'comprehensibility' of the information (five items measured on a 1-5 Likert scale), the 'utility' of the information (composed of quantity and usefulness of six items measured on a 1-3 Likert scale for each dimension), and the 'design quality' of the information (six items measured on a 1-5 Likert scale). The adapted CIRF is composed of the original CIRF by adding an additional question on the intended future use of the information received (three items measured on a 1-5 Likert scale) (14). Furthermore, an extra item exploring bias was added to the 'design quality' question. The adapted CIRF was translated into Dutch using a forward backward translation procedure (19).

The HADS is a validated self-report scale for detecting states of depression and anxiety. It contains two 7-item scales: one for anxiety and one for depression. All 14 items are rated on a 4-point scale from 0 to 3 . Scores are totalled for each subscale (i.e. anxiety and depression) and have a range of 0 21 for each subscale $(20,21)$. In their original study, Zigmond and Snaith recommended cut-off values for both subscales of the HADS: non-cases $(\leq 7)$; doubtful cases (8-10); and definite cases ( $\geq 11)(21)$.

Patient demographic data included gender, age, education, occupation and SSRI use.

Data analysis. Descriptive statistics examined demographic characteristics of the sample. Mean and standard deviation were computed for each item of the adapted CIRF and the HADS. 
Previous studies have indicated that the 17 items of the original CIRF can be grouped into three questions: comprehensibility, utility and design quality $(9,14)$. To explore the construct validity of the CIRF to Flemish inpatients with major depression, the items of the original CIRF were subjected to factor analysis. Factor analysis is a technique that extracts as many factors as there are questions in the set of items that make up the CIRF. As previous studies identified three factors, the number of factors was preset to three in our analysis $(9,14)$. If each item loads on its corresponding question, this would support the use of the CIRF to our patient population. For factor analysis to be appropriate, the Kaiser-Meyer-Olkin measure of sampling adequacy needs to exceed 0.5 and Bartlett's test of sphericity needs to be statistically significant (i.e. $P<0.05)$ (22). The factor analysis was performed by principal component analysis with varimax rotation (23).

The reliability of the CIRF concerns the degree of reproducibility or consistency of the empirical results of the CIRF. Reliability was tested by calculating a Cronbach's alpha coefficient for each factor of the CIRF (24). This measure gives the average of all possible split-half reliabilities of a factor. To obtain a split-half reliability, factor items are randomly divided into two groups, which are then correlated with each other. A value of Cronbach's alpha of 0.7 or more is considered to be adequate for basic research (25).

The data were analyzed using SPSS 15.00 (SPSS Inc., Chicago, IL, USA) for Windows (26).

\section{RESULTS}

\section{Indirect evaluation}

Calculations of the readability scores are included in Appendix 1. The pamphlet had a 'reading ease' score of 70 on a scale from 0 (very difficult) to 100 (very easy). A score of 70 indicates that the pamphlet is in between normal and fairly easy to read and corresponds with an age level of 12-15 years. 'Human interest' had a score of 56 on a scale from 0 (dull) to 100 (dramatic), showing much interest for the reader. Scores for the 'quick reading' test are scaled from 0 (formal) to $\geq 36$ (very popular). The pamphlet had a 'quick reading' score of 42 , corresponding with a very popular pamphlet.
Table 1. Demographic characteristics $(n=96)$

\begin{tabular}{|c|c|}
\hline Characteristics & $\begin{array}{l}\text { Number of } \\
\text { patients }(\%)\end{array}$ \\
\hline Age (Mean \pm SD) (years) & $39 \cdot 61 \pm 12 \cdot 80$ \\
\hline Female & $n=64(66 \cdot 7 \%)$ \\
\hline \multicolumn{2}{|l|}{ Education } \\
\hline Primary school & $n=4(4 \cdot 2 \%)$ \\
\hline $\begin{array}{l}\text { Lower secondary } \\
\text { school (12-15 years) }\end{array}$ & $n=15(15 \cdot 6 \%)$ \\
\hline $\begin{array}{l}\text { Upper secondary } \\
\text { school (16-18 years) }\end{array}$ & $n=32(33 \cdot 3 \%)$ \\
\hline $\begin{array}{l}\text { Education higher than } \\
\text { secondary school }\end{array}$ & $n=43(44 \cdot 8 \%)$ \\
\hline \multicolumn{2}{|l|}{ Occupation } \\
\hline Student & $n=9(9 \cdot 4 \%)$ \\
\hline Household & $n=6(6 \cdot 3 \%)$ \\
\hline Blue collar worker & $n=5(5 \cdot 2 \%)$ \\
\hline White collar worker & $n=55(57 \cdot 3 \%)$ \\
\hline Retired & $n=5(5 \cdot 2 \%)$ \\
\hline Unemployed & $n=3(3 \cdot 1 \%)$ \\
\hline Other & $n=13(13.5 \%)$ \\
\hline \multicolumn{2}{|l|}{ Prescribed SSRI } \\
\hline Citalopram & $n=4(4 \cdot 2 \%)$ \\
\hline Escitalopram & $n=31(32 \cdot 3 \%)$ \\
\hline Fluoxetine & $n=10(10 \cdot 4 \%)$ \\
\hline Fluvoxamine & $n=2(2 \cdot 1 \%)$ \\
\hline Paroxetine & $n=19(19 \cdot 8 \%)$ \\
\hline Setraline & $n=21(21 \cdot 9 \%)$ \\
\hline 2 SSRI's & $n=1(1 \cdot 0 \%)$ \\
\hline Unknown & $n=8(8 \cdot 3 \%)$ \\
\hline
\end{tabular}

SD, standard deviation; SSRI, selective serotonin reuptake inhibitor.

\section{Direct evaluation}

Descriptive analysis. 114 patients participated, of which 96 questionnaires were eligible for analysis. Questionnaires of 18 patients were excluded due to incomplete responses. Patient characteristics are described in Table 1. Patients tended to be middleaged women and had completed secondary school or higher education. The majority of participants were white collar workers. Patients were prescribed escitalopram (32\% of patients), sertraline $(22 \%)$, paroxetine $(20 \%)$ or another SSRI.

The mean and standard deviation for each item of the adapted CIRF are given in Table 2. With respect to 'comprehensibility', patients scored the pamphlet as easy to read, understand and locate information; but as less easy to remember and 
Table 2. Consumer rating of patient pamphlet using the adapted CIRF

\begin{tabular}{|c|c|}
\hline Item & Mean \pm SD \\
\hline \multicolumn{2}{|l|}{ Comprehensibility $^{\mathrm{a}}$} \\
\hline Read & $4 \cdot 22 \pm 0 \cdot 82$ \\
\hline Understand & $4 \cdot 23 \pm 0 \cdot 75$ \\
\hline Remember & $3 \cdot 64 \pm 0 \cdot 86$ \\
\hline Locate information & $4 \cdot 09 \pm 0 \cdot 76$ \\
\hline Keep & $3 \cdot 84 \pm 0 \cdot 83$ \\
\hline Total (range 5-25) & $20 \cdot 02 \pm 3 \cdot 10$ \\
\hline \multicolumn{2}{|l|}{ Future use $^{\mathrm{b}}$} \\
\hline $\operatorname{Read}^{\mathrm{C}}$ & $4 \cdot 47 \pm 0 \cdot 78$ \\
\hline$U_{s e}^{c}$ & $4 \cdot 31 \pm 0 \cdot 77$ \\
\hline Keep ${ }^{c}$ & $4 \cdot 02 \pm 1 \cdot 15$ \\
\hline Total (range 3-15) & $12 \cdot 80 \pm 2 \cdot 13$ \\
\hline \multicolumn{2}{|l|}{ Utility $^{\mathrm{d}}$} \\
\hline Benefits & $3 \cdot 03 \pm 0 \cdot 77$ \\
\hline Contraindications & $3 \cdot 01 \pm 0 \cdot 92$ \\
\hline Directions & $2 \cdot 96 \pm 0 \cdot 79$ \\
\hline Precautions & $3 \cdot 05 \pm 0 \cdot 77$ \\
\hline Adverse effects & $2 \cdot 99 \pm 0.96$ \\
\hline Storage & $2 \cdot 56 \pm 1 \cdot 01$ \\
\hline Total (range 6-24) & $17 \cdot 60 \pm 3 \cdot 30$ \\
\hline \multicolumn{2}{|l|}{ Design Quality $^{\mathrm{e}}$} \\
\hline Organization & $4 \cdot 00 \pm 0 \cdot 77$ \\
\hline Attractiveness & $3.59 \pm 0.99$ \\
\hline Print size & $4 \cdot 14 \pm 0 \cdot 98$ \\
\hline Tone & $4 \cdot 14 \pm 0 \cdot 98$ \\
\hline Helpfulness & $4 \cdot 03 \pm 0 \cdot 85$ \\
\hline Bias $^{c}$ & $4 \cdot 02 \pm 1 \cdot 00$ \\
\hline Spacing & $4 \cdot 15 \pm 0 \cdot 95$ \\
\hline Total (range 7-35) & $28 \cdot 06 \pm 4 \cdot 69$ \\
\hline
\end{tabular}

CIRF, consumer information rating form; SD, standard deviation.

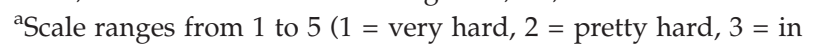
between, 4 = pretty easy, 5 = very easy).

${ }^{\mathrm{b}}$ Scale ranges from 1 to 5 ( 1 = very unlikely, 2 = somewhat unlikely, 3 = unsure, 4 = somewhat likely, 5 = very likely).

cExtra items added to the original CIRF. Combination of the 4 items and the original CIRF is called the adapted CIRF.

${ }^{\mathrm{d} C}$ Composite scale: $(1=$ not so useful, 2 = fairly useful, $3=$ very useful $)+(0=$ too little or too much information, $1=$ right amount of information).

${ }^{\mathrm{e}} \mathrm{S}$ cale ranges from 1 to 5 ( $1=$ low quality $\rightarrow 5=$ high quality)

keep. Regarding the 'future use' of the pamphlet, patients reported that they were likely to read, use and keep the pamphlet. The information in the pamphlet was rated as useful and had been provided in a sufficient amount; but the topic 'storage' was found to be somewhat less useful than the other topics. Apart from attractiveness, all design topics were scored to be of good quality.

Table 3 summarises the scores on the HADS including the distribution over no case, doubtful and definite case; but also the mean score and the range of scores observed in our population.

Exploration of construct validity. The construct validity of the original CIRF to our patient population was assessed by comparing the factors generated by the factor analysis with the original questions (see Table 4). The Kaiser-Meyer-Olkin measure of sampling adequacy was $0 \cdot 777$, thus exceeding the benchmark of 0.5. Also, Bartlett's test of sphericity was significant $\left(\chi^{2}=598,768\right.$; $\mathrm{df}=136 ; \quad P<0 \cdot 001)$. Both tests confirmed the appropriateness of performing a factor analysis. Sixteen of the 17 items loaded on the corresponding question, supporting the construct validity of the CIRF. The only exception was the item 'benefits', which loaded on the corresponding question of 'utility', but also cross-loaded on the question of 'design quality'.

Table 4 also shows that values of Cronbach's alpha ranged from 0.69 to $0 \cdot 83$, equalling the benchmark of 0.7 . This points to a high reliability of the CIRF questions.

These results support the construct validity of the CIRF in a population of Dutch-speaking inpatients with major depression.

\section{DISCUSSION}

A first aim of this study was to evaluate a patient pamphlet on SSRI antidepressants. Our direct and indirect evaluation supported the quality of the pamphlet in terms of readability. The results of the indirect evaluation based on readability formulae were corroborated by the direct evaluation of the consumer's opinion on the readability of the pamphlet in our study. Both methods have their value in producing and evaluating written medication information. While formulae are practical tools to evaluate readability during the conception phase of a pamphlet, direct evaluation can be used to confirm the results of readability scores from the consumer's perspective before the pamphlet is distributed. Additionally, direct evaluation showed that the pamphlet was likely to be used in the future and had a satisfying utility and a good design quality. These 
Table 3. Results of the hospital anxiety and depression scale $(n=96)$

\begin{tabular}{|c|c|c|c|c|c|c|}
\hline & $\begin{array}{l}\text { Non } \\
\text { cases } \\
(0-7)\end{array}$ & $\begin{array}{l}\text { Doubtful } \\
\text { cases } \\
(8-10)\end{array}$ & $\begin{array}{l}\text { Definite } \\
\text { cases } \\
(\geq 11)\end{array}$ & $\begin{array}{l}\text { Mean score } \\
\pm \text { standard } \\
\text { deviation }\end{array}$ & $\begin{array}{l}\text { Lowest } \\
\text { score } \\
\text { observed }\end{array}$ & $\begin{array}{l}\text { Highest } \\
\text { score } \\
\text { observed }\end{array}$ \\
\hline Anxiety & $n=26$ & $n=21$ & $n=48$ & $10 \cdot 65 \pm 4 \cdot 90$ & 0 & 21 \\
\hline Depression & $n=43$ & $n=16$ & $n=37$ & $8 \cdot 91 \pm 5 \cdot 23$ & 0 & 20 \\
\hline
\end{tabular}

Spearman's rho correlation coefficients for Anxiety scores and Depression scores is 0.795 ( $P \leq 0 \cdot 001$; 2-tailed).

\begin{tabular}{|c|c|c|c|c|}
\hline & Factor 1 & Factor 2 & Factor 3 & \\
\hline Read & $0 \cdot 820$ & & & \\
\hline Understand & $0 \cdot 771$ & & & \\
\hline Remember & $0 \cdot 789$ & & & \\
\hline Locate & $0 \cdot 757$ & & & \\
\hline Keep & $0 \cdot 543$ & & & \\
\hline Organization & & 0.565 & & \\
\hline Attractiveness & & $0 \cdot 768$ & & \\
\hline Print size & & $0 \cdot 738$ & & \\
\hline Tone & & $0 \cdot 641$ & & \\
\hline Helpfulness & & $0 \cdot 647$ & & \\
\hline Spacing & & $0 \cdot 758$ & & \\
\hline Benefits & $0 \cdot 439$ & & $0 \cdot 591$ & \\
\hline Contraindications & & & 0.606 & \\
\hline Directions & & & 0.599 & \\
\hline Precautions & & & $0 \cdot 706$ & \\
\hline Side effects & & & $0 \cdot 540$ & \\
\hline Storage & & & $0 \cdot 651$ & \\
\hline Factor name & $\begin{array}{l}\text { Consumer } \\
\text { comprehensibility } \\
\text { rating scale }\end{array}$ & $\begin{array}{l}\text { Consumer } \\
\text { design } \\
\text { quality } \\
\text { rating scale }\end{array}$ & $\begin{array}{l}\text { Consumer } \\
\text { utility } \\
\text { rating scale }\end{array}$ & \\
\hline Eigenvalue & $5 \cdot 056$ & $2 \cdot 337$ & $1 \cdot 612$ & \\
\hline $\begin{array}{l}\text { Variance } \\
\text { explained }\end{array}$ & $29 \cdot 74 \%$ & $13 \cdot 75 \%$ & $9 \cdot 48 \%$ & Total: $52 \cdot 97 \%$ \\
\hline $\begin{array}{l}\text { Cronbach's } \\
\text { alpha }\end{array}$ & $0 \cdot 830$ & $0 \cdot 823$ & $0 \cdot 690$ & \\
\hline
\end{tabular}

Table 4. Factor solution of CIRF

Factor loadings smaller than $0 \cdot 4$ are not included in the table.

results show that the SSRI pamphlet was well accepted by patients taking antidepressants.

A second aim of this study was to explore the construct validity of the CIRF to Flemish inpatients with major depression. The factor analysis on the original items of the CIRF showed that 16 of the 17 items loaded on the corresponding question, supporting the use of the CIRF to this population. The items corresponded with the same three subscales as in previous studies: consumer comprehensibility, consumer utility and consumer design quality $(9,14)$. The total variance explained approximates the variance explained in the Australian study, which was much lower than in the US study $(9,14)$. The differences between these three studies may be attributed to the nature and the size of the consumer samples. In the US study a convenience sample of 24 persons of a consumer evaluation panel evaluated a selection of patient information leaflets. In the Australian 
( $n=282)$ and the current $(n=96)$ study, patients evaluated information on their own medication. In the last two studies, consumers may score the written medication information differently as the information may potentially influence their own behaviour to medicines (14). Finally, the Cronbach alpha scores supported the reliability of the three CIRF subscales.

Our patient sample consisted of patients with a major depression who got an SSRI antidepressant prescribed. Half of the Belgian patients who need an antidepressant, get a SSRI prescribed (18). In Belgium, the prescription of SSRIs does not have restrictions in hospitals as well as in ambulatory care. Reimbursement data of the National Social Insurance Agency in Belgium (RIZIV, Rijksinstituut voor Ziekte- en Invaliditeitsverzekering) showed that the amount of SSRI prescribed (expressed as Daily Defined Dose) has doubled in the last decade while the population remained stable. All age groups received SSRI antidepressants (27). This means that young patients as well as older patients can get an SSRI prescribed. Additionally, first line pharmacotherapy comprises of SSRI antidepressants as well as tricyclic antidepressants (28).

Regarding the demographic characteristics of our patient sample, about half of them are white collar workers. This high percentage of white collar workers may be due to the willingness to participate in the study. This may be a confounding factor for which we did not control in our study.

This study measured the HADS score in this patient population. The scores on the HADS subscales showed that, in addition to depressive symptoms, anxiety symptoms are present in this patient population (see Table 3), corroborating international evidence that anxiety and depression often coexist (29).

This study included hospitalized adult patients with major depression. They evaluated the patient pamphlet a few days before hospital discharge. Following discharge, patients are again responsible for their own medication intake and, therefore, the information of the pamphlet can support patients in taking their medicines. This entails that patients in an acute phase of depression (i.e. at the moment of hospital admission) are no part of this study. The HADS was completed at the time of the pamphlet evaluation which explains the moderate scores on the HADS.
These results are valid for inpatients only as no ambulatory patients were enrolled. While pamphlets are available on other groups of antidepressants (e.g. tricyclic antidepressants), our analysis studied the pamphlet on SSRI antidepressants as SSRIs make up half of the antidepressant use by Belgian patients (18). Further research is needed into the use of the CIRF in other patient populations in different settings.

\section{CONCLUSION}

Our study indicated that the SSRI pamphlet, on the one hand, had good readability scores and, on the other hand, was well accepted by patients with major depression taking SSRI antidepressants. Also, our study supported the construct validity of the CIRF to Flemish inpatients with major depression.

\section{ACKNOWLEDGEMENTS}

This research was supported by a grant of the Institute for the Promotion of Innovation through Science and Technology in Flanders (IWT-Vlaanderen). We would like to thank Professor Ines Krass for her permission and advice on the use of the CIRF. We would also like to thank the Flemish Association of Hospital Pharmacist (division of psychiatry) for their constructive collaboration and the use of the SSRI pamphlet.

The authors have no conflicts of interest that are directly relevant to the content of this manuscript.

\section{REFERENCES}

1. Coulter A, Ellins J, Swain D et al. (2006) Assessing the quality of information to support people making decisions about their health and healthcare. Available at: http://www.pickereurope.org/Filestore/ Downloads/Health-information-quality-web-versionFINAL.pdf (Accessed 2009 Feb 15).

2. Desplenter FA, Simoens S, Laekeman G (2006) The impact of informing psychiatric patients about their medication: a systematic review. Pharmacy World \& Science, 28, 329-341.

3. U.S.Department of Health and Human Services, FDA, CDER, and CBER (2006) Guidance: useful written consumer medication information. Available at: http://www.fda.gov/CDER/GUIDANCE/7139fnl. htm (Accessed 2009 Feb 15). 
4. Kenny T, Wilson RG, Purves IN, Clark J, Newton LD, Newton DP, Moseley DV (1998) A PIL for every ill? Patient information leaflets (PILs): a review of past, present and future use Family Practice, 15, 471-479.

5. Newton L, Newton D, Clark J, Kenny T, Moseley D, Purves I, Wilson R (1998) Patient information leaflets: producing understandable PILs. Journal of Information Science, 24, 167-181.

6. Fitzmaurice DA, Adams JL (2000) A systematic review of patient information leaflets for hypertension. Journal of Human Hypertension, 14, 259-262.

7. Wyatt JC (2000) Information for patients. Journal of the Royal Society of Medicine, 93, 467-471.

8. Blenkinsopp A, Bashford J, Dickinson D (1998) Health porfessionals need to identify how much information patients want. British Medical Journal, $317,413$.

9. Krass I, Svarstad BL, Bultman D (2002) Using alternative methodologies for evaluating patient medication leaflets. Patient Education and Counseling, 47, 29-35.

10. Flesch R (1948) A new readability Yardstick. Journal of Applied Psychology, 32, 221-233.

11. Dickinson D, Raynor DK, Duman M (2001) Patient information leaflets for medicines: using consumer testing to determine the most effective design. Patient Education and Counseling, 43, 147-159.

12. Beaver K, Luker K (1997) Readability of patient information booklets for women with breast cancer. Patient Education and Counseling, 31, 95-102.

13. Horner SD, Surratt D, Juliusson S (2000) Improving readability of patient education materials. Journal of Community Health Nursing, 17, 15-23.

14. Koo MM, Krass I, Aslani P (2007) Evaluation of written medicine information: validation of the consumer information rating form. The Annals of Pharmacotherapy, 41, 951-956.

15. Laekeman G, Leemans L (1999) Communicatie in de apotheek [Communication in the pharmacy]. Leuven/Amersfoort: Acco.

16. Flesch R (1977) Meten van leesbaarheid [Measuring readability]. In: Banis $M$, Huismans $M$, Klaui E, eds. Helder schrijven, spreken, denken: stap voor stap naar betere communicatie [How to write, speak and think more effectively]. Deventer: Van Loghum Slaterus, 279-297.

17. Zwaenepoel L, Bilo R, De Boever W et al. (2005) Desire for information about drugs: a survey of the need for information in psychiatric in-patients. Pharmacy. World \& Science, 27, 47-53.

18. De Bruyn K, Gilson D (2007) Antidepressiva in België [Antidepressants in Belgium]. Apothekersblad $(A P B), \mathbf{5 8}, 12-17$.

19. Cull A, Sprangers M, Bjordal K, Aaronson N, West $\mathrm{K}$, Bottomley A (2002) EORTC quality of life group translation procedure. Available at: http://groups. eortc.be/qol/downloads/200202translation_manual. pdf (Accessed 2009 Feb 15).

20. Spinhoven P, Ormel J, Sloekers PPA, Kempen GIJM, Speckens AEM, Van Hemert AM (1997) A validation study of the Hospital Anxiety and Depression Scale (HADS) in different groups of Dutch subjects. Psychological Medicine, 27, 363-370.

21. Zigmond AS, Snaith RP (1983) The hospital anxiety and depression scale. Acta Psychiatrica Scandinavica, 67, 361-370.

22. Newcastle University. How to perform and interpret factor analysis using SPSS. Available at: http:// www.ncl.ac.uk/iss/statistics/docs/factoranalysis. php (Accessed 2008 Jan 9).

23. Staquet MJ, Hays RD, Fayers PM (1998) Quality of life assessment in clinical trials. Methods and practice. Oxford: Oxford University Press.

24. Cronbach LJ (1951) Coefficient alpha and the internal structure of tests. Psychometrika, 16, 297-334.

25. Bland JM, Altman DG (1997) Cronbach's alpha. British Medical Journal, 314, 572.

26. SPSS Inc (2006) SPSS 15.00 for windows. Statistical package for the social sciences. Chicago: SPSS Inc.

27. RIZIV (Rijksinstituut voor Ziekte- en Invaliditeitsverzekering) Farmaceutische Kengetallen 2006 [Pharmaceutical Index Numbers] (July 2008). Available at: http://www.riziv.fgov.be/drug/nl/statisticsscientific-information/pharmanet/pharmaceuticaltables/index.htm (Accessed 2009 Feb 15).

28. Heyrman J, Declercq T, Rogiers R et al. (2008) Depressie bij volwassenen: aanpak door de huisarts [Adults with depression: treatment by the general practitioner]. Huisarts $N u, 37,284-317$.

29. Baldwin DS, Evans DL, Hirschfeld RM, Kasper S (2002) Can we distinguish anxiety from depression? Psychopharmacology Bulletin, 36(Suppl 2), 158165. 
APPENDIX 1. FLESCH-DOUMA READABILITY FORMULAE $(10,15,16)$

\begin{tabular}{lll}
\hline Reading ease score & Style description & Education level \\
\hline $90-100$ & Very easy & Primary school: $4^{\text {th }}$ year \\
$80-90$ & Easy & Primary school: $5^{\text {th }}$ year \\
$70-80$ & Fairly easy & Primary school: $6^{\text {th }}$ year \\
$60-70$ & Normal & Lower technical school \\
$50-60$ & Fairly difficult & Upper secondary school \\
$30-50$ & Difficult & Higher education \\
$0-30$ & Very difficult & University \\
\hline
\end{tabular}

Reading ease score $=207-(\mathrm{Z}+\mathrm{W})$ with $\mathrm{Z}=(\#$ words/\# sentences $) \times 0.93$ and $\mathrm{W}=(\#$ syllables/\# words $) \times$ $100 \times 0.77$.

SSRI pamphlet: $207-[(644 / 84) \times 0 \cdot 93+(1086 / 644) \times 100 \times 0 \cdot 77]=70$.

\begin{tabular}{ll}
\hline Personal interest score & Style description \\
\hline $60-100$ & Dramatic \\
$40-60$ & Highly interesting \\
$20-40$ & Interesting \\
$10-20$ & Mildly interesting \\
$0-10$ & Dull \\
\hline
\end{tabular}

Human interest score $=\mathrm{PZ}+\mathrm{PW}$ with $\mathrm{PZ}=[(\#$ personal sentences $\times 100) / \#$ sentences $] \times 0 \cdot 32$ and $\mathrm{PW}=[(\#$ personal words $\times 100) / \#$ words] $\times 3 \cdot 7$.

SSRI pamphlet: $[((26 \times 100) / 84) \times 0 \cdot 32]+[((81 \times 100) / 644) \times 3 \cdot 7]=56$.

Quick reading test score

Style description

$0-20$

Formal

21-25

Informal

26-30

Fairly popular

31-35

Popular

$\geq 36$

Very popular

Quick reading test score $=(\#$ points/\# words $) \times 100$.

With points accorded for capitals, italic, bold or underlined words, numbers, punctuations marks, symbols and the beginning and the end of a paragraph.

SSRI pamphlet: $(271 / 644) \times 100=42$.

\section{APPENDIX 2. SSRI PAMPHLET}

Patiëntenfolder nr. 2

\section{ANTIDEPRESSIVA: SSRI'S}

\section{Waarom werd mij een SSRI voorgeschreven?}

Eén op vijf personen is wel eens depressief in de loop van zijn leven. Je voelt je dan vaak droevig, leeg en teneergeslagen. Je mist energie en de interesse voor je werk of hobby's neemt af. Je valt moeilijk in slaap of wordt vroeg wakker. Als die symptomen enkele weken duren en ze je normale leven in de war sturen, kunnen SSRI antidepressiva (SSRI's) helpen. 


\section{Wat zijn SSRI's?}

SSRI's zijn geen kalmeermiddelen of slaaptabletten.

Ze zijn een groep geneesmiddelen die helpen bij depressie. SSRI staat voor Selectieve Serotonine Reuptake Inhibitor. Dat betekent dat ze werken op één van de belangrijkste chemische stoffen in de hersenen bij depressie, namelijk serotonine. De SSRI's zijn even effectief als de andere groepen antidepressiva. Duizenden mensen nemen deze geneesmiddelen en kunnen nu een normaal leven leiden. Momenteel neem jij:

\section{Zijn SSRI's veilig?}

SSRI's zijn veilig als je als je het voorschrift van je dokter goed volgt.

Licht echter steeds je dokter in:

- wanneer je lijdt aan epilepsie of diabetes of als je problemen hebt met je lever of nieren;

- over welke geneesmiddelen jij op het ogenblik inneemt;

- of je zwanger bent of wenst te worden;

- als je borstvoeding wenst te geven.

Je hebt een doktervoorschrift nodig als je je SSRI antidepressivum wilt halen bij de apotheker.

Bewaar je geneesmiddel buiten het bereik van kinderen en geef het nooit door aan anderen.

\section{Hoe moet ik mijn SSRI innemen?}

Hou je steeds aan de voorgeschreven dosis en volg de richtlijnen van je dokter goed op. Ben je eens vergeten je SSRI in te nemen, dan kan dit nog na enkele uren, maar neem geen dubbele dosis. Je neemt je SSRI tijdens de maaltijden.

\section{Wat voel ik na de inname van mijn SSRI?}

Je kan je wel wat opgewonden voelen de eerste week. Ook je slaap kan beïnvloed worden. Het duurt toch twee tot vier weken vooraleer je je echt beter voelt. Geef vooral niet op! Je zal je na enkele weken veel kalmer voelen en je zult je beter kunnen concentreren. Alle dagen zullen echter niet gelijk zijn, maar dat is normaal. Geef je geneesmiddel de tijd om te werken!

\section{Zijn er bijwerkingen met SSRI antidepressiva?}

In het begin kun je je wat ongemakkelijk voelen. De klachten zijn meestal niet ernstig en ze verdwijnen na ongeveer een week. Bekijk de volgende tabel om te weten wat je moet doen als je één van de bijwerkingen ondervindt. Let wel! Niet iedereen heeft daar last van.

\begin{tabular}{llll}
\hline BIJWERKING & WAT IS HET? & $\begin{array}{l}\text { IS DIT } \\
\text { NORMAAL? }\end{array}$ & WAT MOET IK DOEN? \\
\hline $\begin{array}{l}\text { Nausea en } \\
\text { braken }\end{array}$ & $\begin{array}{l}\text { Je voelt je } \\
\text { misselijk. }\end{array}$ & Ja & $\begin{array}{c}\text { Neem je geneesmiddel tijdens of } \\
\text { na de maaltijd. Raadpleeg je dokter } \\
\text { als het te erg wordt. }\end{array}$ \\
$\begin{array}{llll}\text { Insomnia } \\
\text { Slaperigheid }\end{array}$ & $\begin{array}{l}\text { Je kan niet goed slapen. } \\
\text { Je voelt je slaperig. }\end{array}$ & $\begin{array}{l}\text { Ja } \\
\text { Bespreek het met je dokter. } \\
\text { Pas op bij het besturen van voertuigen } \\
\text { of machines. }\end{array}$ \\
\hline
\end{tabular}




\begin{tabular}{|c|c|c|c|}
\hline BIJWERKING & WAT IS HET? & $\begin{array}{l}\text { IS DIT } \\
\text { NORMAAL? }\end{array}$ & WAT MOET IK DOEN? \\
\hline Hoofdpijn & & Ja & $\begin{array}{l}\text { Vraag je apotheker een middel op basis } \\
\text { van paracetamol. }\end{array}$ \\
\hline Rusteloosheid & $\begin{array}{l}\text { Je voelt je opgewonden } \\
\text { en je hart klopt sneller. } \\
\text { Je kan ook meer zweten. }\end{array}$ & Ja & Raadpleeg je dokter als het te erg wordt. \\
\hline Seksuele disfunctie & $\begin{array}{l}\text { Je komt moeilijk tot een } \\
\text { orgasme. }\end{array}$ & $\mathrm{Ja}$ & Spreek erover met je dokter. \\
\hline Andere bijwerkingen & & & $\begin{array}{l}\text { Indien je nog een andere bijwerking zou } \\
\text { voelen, bespreek dat dan zo snel mogelijk } \\
\text { met je dokter. }\end{array}$ \\
\hline
\end{tabular}

\section{Mag ik alcohol drinken?}

In het begin van je behandeling met je antidepressivum is het beter om geen alcohol te drinken. Nadien, als je je reeds wat beter voelt, is het je toegelaten met mate te drinken, maar laat in geen geval na je geneesmiddel in te nemen.

\section{Ik voel me beter. Mag ik nu al stoppen?}

Neen, nu je je beter voelt, mag je niet plots stoppen. Anders gaan je klachten zeker terug de kop opsteken. Je zal je SSRI nog minstens 4 tot 6 maanden verder nemen. Dat is niet schadelijk! Je geneesmiddel veroorzaakt geen verslaving. 